\title{
Mental health and psychiatric nursing: contributions to the resocialization of person in psychic suffering
}

Cristina Maria Douat Loyola

1. Full Professor (Retired). Escola de Enfermagem Anna Nery. Universidade Federal do Rio de Janeiro. Member of the Permanent Faculty of the Master in Program and Health Services Management at Universidade CEUMA. Invited Professor of the Master's Degree in Mental Health at the Instituto de Pisiquiatria/IPUB. Universidade Federal do Rio de Janeiro. Brazil.
We are in favor of our patients passing from one place to another, a better place, being happier (if normal, re-socialized, or rehabilitated, I do not know), and we will fight for this goal and with the means we have (the mental health network/Psychosocial Health Care Network "RAPS" and other social bonds). We must have some mental health, since there is no health, without mental health. Serious mental disorder has the strength to block the harmony of the functioning of perfect organs, and their ability to sustain life. Lungs that oxygenate, kidneys that filter, heart that pumps can compose a biologically healthy individual, but who might not stand to leave the bed, the house, for living, to get out of pain, because it is depressed, and can even commit suicide. We are more than the sum of healthy and functioning biological systems.

In this perspective, having mental health, can also be defined as, fit in life, and some achieve this with greatness, others with great difficulty. It is in this look that we will discuss the title of this issue of the magazine: "Mental Health and Psychiatric Nursing: contributions to the resocialization of the person in psychic suffering". The title is careful, when using resocialization instead of rehabilitation, these performative words which have sparked discussion in the field of mental health. In any case, we retain a certain sin of the prefix "re", which always refers to the search for something that has already been, or which must be re-taken, or revived, fearful expectation, when it comes to psychic suffering or mental disease. Because it takes around ten years, from the first symptoms of mental illness or psychic suffering, until the arrival in a place of health care, and in this path, the life of relations, this same of the social, of the collective feeling, of solidarity, is shaping and impoverishing.

So re-socializing, in this focus of analysis, lacks initial chronology. From what moment was socialization good and should it be resumed? For this reason, re-socialization must take the form of clinical intervention in psychic suffering, permanent socialization, and it is something that must be within the action of caring, as a therapeutic guide, and not as something optional, or only for patients with long diagnosis time. We must be careful to look at the social, at the collective, without getting lost in the intricate ways. I am talking about collective actions to entertain, from workshops to keep busy, within the psychiatric speech. As Saraceno ${ }^{1}$ says: it is the breakdown of entertainment, the indiscipline of life that has actions that are more effective transforming the life of the subjects. It goes for any person, any of us, not "them", only. In fact, micro ruptures of a menu of small entertainments are what can open and show sources of resources and ways of operating until then unimaginable.

And what about us of nursing, what can we? Well, working in psychiatric nursing is to get interested in everything that was once considered "unscientific." It is a team that bets that something can move from inertia, that repetition can have failures, and that we always work on what the subject has, and not on what is lacking, hence why we must work from the symptom and not from the elimination of the symptom. We are a certain counter to the discourse of evidence-based medicine, and this produces much discomfort and uncertainty. This solution, possible for the subject, the symptom, is not the symptom of the surgical clinic, to be annulled, but rather a question to be reflected on. Who orders care, is the subject, we will assist, producing a paradoxical treatment, because the treatment only walks, if it fails: "this fickles, this fails, this goes...", this is how the psychic operates. And when the symptom empties, it does not mean CURE, because in fact there is no external side in the psychic, where you can throw away what is useless. As Estamira ${ }^{2}$ says, there is no "outside" in the psychic, a kind of garbage, and we must learn to live with this precariousness.

The symptom exists to be operated and not eliminated, and what a person says is not the same as what one declares. For our care clinic, the symptom is made of encrypted message and pleasure, and it is the best that the subject has been able to do for him, the 
possible mooring. It is no longer a matter of deciding what the other (client, family) should do, but appropriate the task together, which implies intimacy, close and everyday contact. And having intimacy is not the same as being intimate and here we have another challenge. The nursing professional is trained to intervene, decide, determine, and is confronted in psychiatric nursing, with a work that implies, daily, negotiating, combining, signing contracts, renegotiating and making responsible. Care must be determined from the characteristics of the cared, and the ability of caregivers to use what they learn from them. It is therefore the result of lifelong learning as an anchor point, and this is the opposite of what is generally taught in health.

The definition that health is not just absence of disease compels us to explore the meaning of this announced. It implies that when there is illness, there is no forceful, loss of all health but change, modification. It is not everything, or nothingness. It is important to learn to use what is left of health, that is, life skills, to fight the disease instead of focusing solely on the disease itself. We have to deal with five questions: There is no total coincidence between madness and disease; The dangerousness, as a diagnostic instance may fail, especially in Primary Care; Mental illness is a human experience, what differs is the depth and extent of this experience; Mental illness has treatment and cure
(50\% cure, 30\% need protection for "normal" life, 20\% severe and chronic evolution); No one will sleep normal and wake up crazy, there are traces. Caring, in psychiatric nursing, requires a more empty position, it is different from the "compulsion to care", which has already led us to shaved heads in hospices to "prevent" pediculosis. It is a teamwork partnership that is shaped by work, and an imaginary group glue (which contrasts with corporatism). Caring here as a knowledge, which exits the knowledge exposed from theories and techniques, to the supposed knowledge - the subject as a power. ${ }^{3}$ Where the a priori of scientific knowledge, must be put between quotation marks, to highlight the elements provided by the subject, leaving the common place. To take care of life, of this infinite clew. Attention is the best of solidarities.

\section{REFERENCES}

1. Saraceno B. Libertando identidades: da reabilitação psicossocial à cidadania possível. $1^{\underline{a}}$ ed. Rio de Janeiro: Editora Te Corá; 1999. 176 p.

2. Juhas RT, Santos NO. Ainda em cartaz, Estamira: A psicanálise nas telas do Cinema. Rio de Janeiro, Estud Psicanal [internet]. 2011 Dec [cited 2017 May 14]; 36:157-64. Available from: http://pepsic.bvsalud. org/scielo.php?script=sci_arttext\&pid=S0100-34372011000300015

3. Rocha S, Loyola CMD, organizadores. Cuidando do Futuro: Redução da mortalidade materna e infantil no Maranhão. $1^{\text {a }}$ ed. Belo Horizonte: Centro Popular de Cultura e Desenvolvimento; 2012. 304 p. 